\title{
Budapest's Statue Park and House of Terror
}

\section{KAREN VIRAG}

A friend and colleague, Evgenia Stoyanova, recently spent time working for the UN in Ukraine. She told me about a dance performance she attended while in Kiev:

It was a spectacular show put on by the National Ballet of Ukraine for Yushenko's inauguration (Virski), a modern ballet with Ukrainian folk motifs, and it involved a dance where a communist statue (with the workers, soldiers, the red star, the cannon, the whole deal) comes to life and all the characters tell their story. It is a magnificent piece of art. Amazing to watch! Look at the irony, though. It was a commemoration to all those heroes of the past (the proletariat who built socialism) at the inauguration of Yushenko, who was to be the first Ukrainian president to lead Ukraine to a new era of true independence from Russia .

These images of granite socialist realist statues doing Cossack squat thrusts dancing through my head seems a perfect point of departure for a discussion of socialist realist art, Budapest's open air museum of communism, the Statue Park, and a kind of companion museum, the House of Terror.

SOCIALIST REALIST ART, OR THE PERFECTIBILITY OF

THE FUTURE. AS IF.

Public art and monuments reflect important aspects of a people's identity or fundamental beliefs or aesthetic sensibilities. Monuments such as statues are "messages of power" (Boym 89), and they are meant to last a long time, thereby bridging the gap of generations by embodying unifying myths. Destroying such objects disrupts collective identity and is an effective way for one group to assert domination over another. The concerted wholesale destruction of public images by governments has many precedents, as exemplified by Lenin's 1918 announcement under 
what must be one of the longest headlines in the history of journalism: "The Removal of Monuments Erected in Honour of the Tsars and Their Servants and the Production of Projects for Monuments to the Russian Socialist Revolution." In his announcement, Lenin noted that he wanted to put the unemployed to work toppling the old tsarist statues and erecting new ones to celebrate such revered figures as Marx, Engels, Robespierre, Spartacus, Tolstoy, Dostoevsky, Chopin and Byron (Clark 79). Lenin wanted to convey the notion that the ethos of art was education, so each new politically correct statue would bear a plaque with a brief biography and history lesson to educate the masses. To all accounts, Lenin allowed sculptors surprisingly free rein, which encouraged public discussions about art. Things did not stay rosy for too long, though. As art historian Toby Clark (1997) tells us, "This relative freedom and the modest scale of the statues contrasts with the later conformity of Stalinist monumentalism though Lenin's plan would be cited as a precedent for the monstrous statues of political leaders."

And indeed, in 1934, Stalin formally defined and prescribed socialist realism as the official aesthetic of the Soviet Union, and such aesthetic prescriptions and proscriptions would be imposed on communist states throughout the world, including Hungary, which became part of the Soviet area of influence when, following a short period of democracy in 1946-1947, Communist leader Mátyás Rákosi established a Stalinist rule in the country. This led, among other things, to the adoption of socialist realist art as a principal style of artistic production. And I say production not representation because socialist realism is essentially an "officially sanctioned way of making the world (available)" (Rév 2005, 263) rather than a mode of representation, and the sanctioning power to represent in this case belonged to the Communist Party, which felt that art must be based on four principles: it must reflect people's concerns; class consciousness; the Party's views, and it must be current (Clark 87).

This is all fine and good, but the regime had a problem on its hands how to handle the divide between art as "high culture" and the generally plebeian tastes of the common worker, who would rather go to a soccer match than an art gallery. "The solution was to merge fine art with mass culture, first, with the mass reproduction of paintings and sculptures in films, postcards, advertisements and magazines, which shift the sites of reception and confer a sense of common ownership over the image, and second, by the stylistic adaptation of art to the visual codes of popular culture - by making a painting look like a movie poster, for example 
(Clark 61). The result is kitsch, a German word that refers to massproduced art or artifacts that are somehow inferior, pretentious, trite, or in bad taste, as in prints of poker-playing dogs.

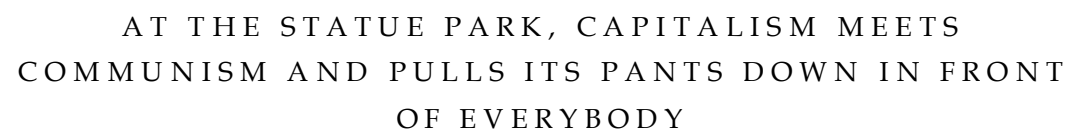

In December of 2003, Pál and Agi Haiman took their cousin and my friend Juliet Kershaw and me to Budapest's Statue Park. Unlike most other former Eastern bloc peoples, after the system change, the Hungarians did not smash the Communist era statues to smithereens (with the exception of a statue of Stalin that was smashed in the '56 revolution). Instead, they re-erected them in an "outdoor museum."

In July of 1989 the Hungarian literary historian László Szörényi suggested the creation of such a park to quell a debate over what to do with all the statues dating from the communist system, which fell in 1989/90 (commentators [e.g., Bandy 2004] have noted that unlike the dramatic fall of the Berlin Wall, the so-called system change in Hungary wasn't so much a fall as a deflation, much like what happens to a soufflé taken out of the oven too soon). So, in December of 1991, the Budapest Assembly issued a tender for "plans as to the future of the statues." The Budapest architect Ákos Eleőd won, and the park, known in Hungarian as Szobor Park (simply Statue Park), was officially opened in the autumn of 1993 on a site about twenty minutes from central Budapest. At the official dedication early in '94, the architect Eleöd had this to say:

This park is a very delicate matter. I've been trying my utmost to treat this terribly serious theme with the proper amount of seriousness. But what is Truth? Of course, I can't answer that. But there's plenty of time to think about it. I had to realise that if I constructed this park with more tendentious, extreme or realistic methods - as a number of people were expecting - I would ultimately be doing nothing more than constructing my own anti-propaganda park from these propagandist statues, and following the same thought patterns and prescriptions of dictatorship that erected these statues in the first place.

This park is about dictatorship. And at the same time, because it can be talked about, described, built, this park is about democracy. After all, only democracy is able to give the opportunity to let us think freely about dictatorship. Or about democracy. Or about anything.

As we approached the Park on that grey December day, the steely gaze of Lenin met us from one side and that of Marx and Engels from the other 
as loud speakers played martial music. Once past the entrance, one enters a space that contains about forty statues, plaques and murals laid out around a red star in three figure-eights. Statues include busts of former communist leaders, both international and local; big-calved workers with unnaturally large hands, all the better to bring in the sheaves with; and martyrs, all with heads uplifted, staring unblinkingly into the future. I am sure they never saw themselves ending up here.
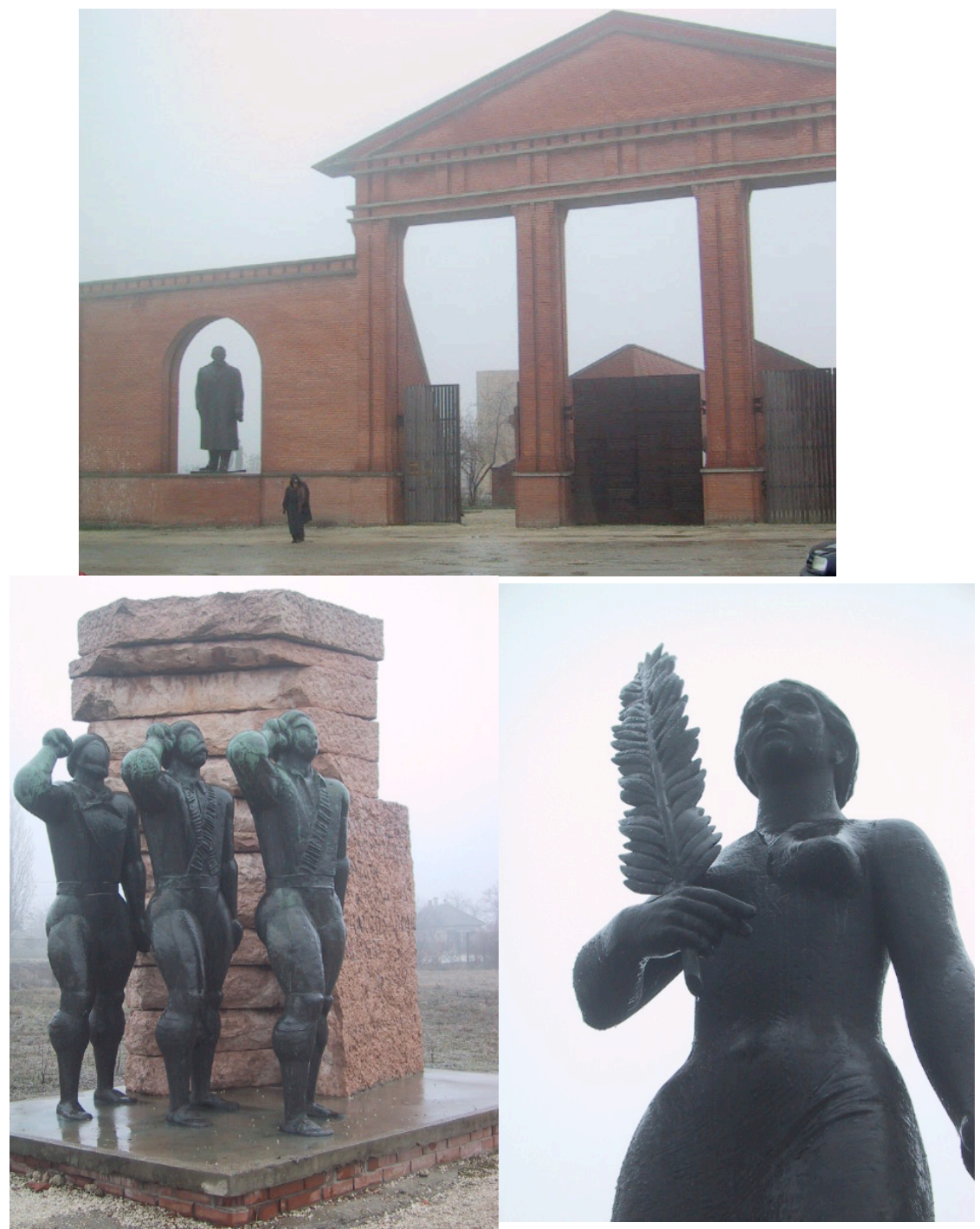

All photos $@$ Juliet Kershaw 

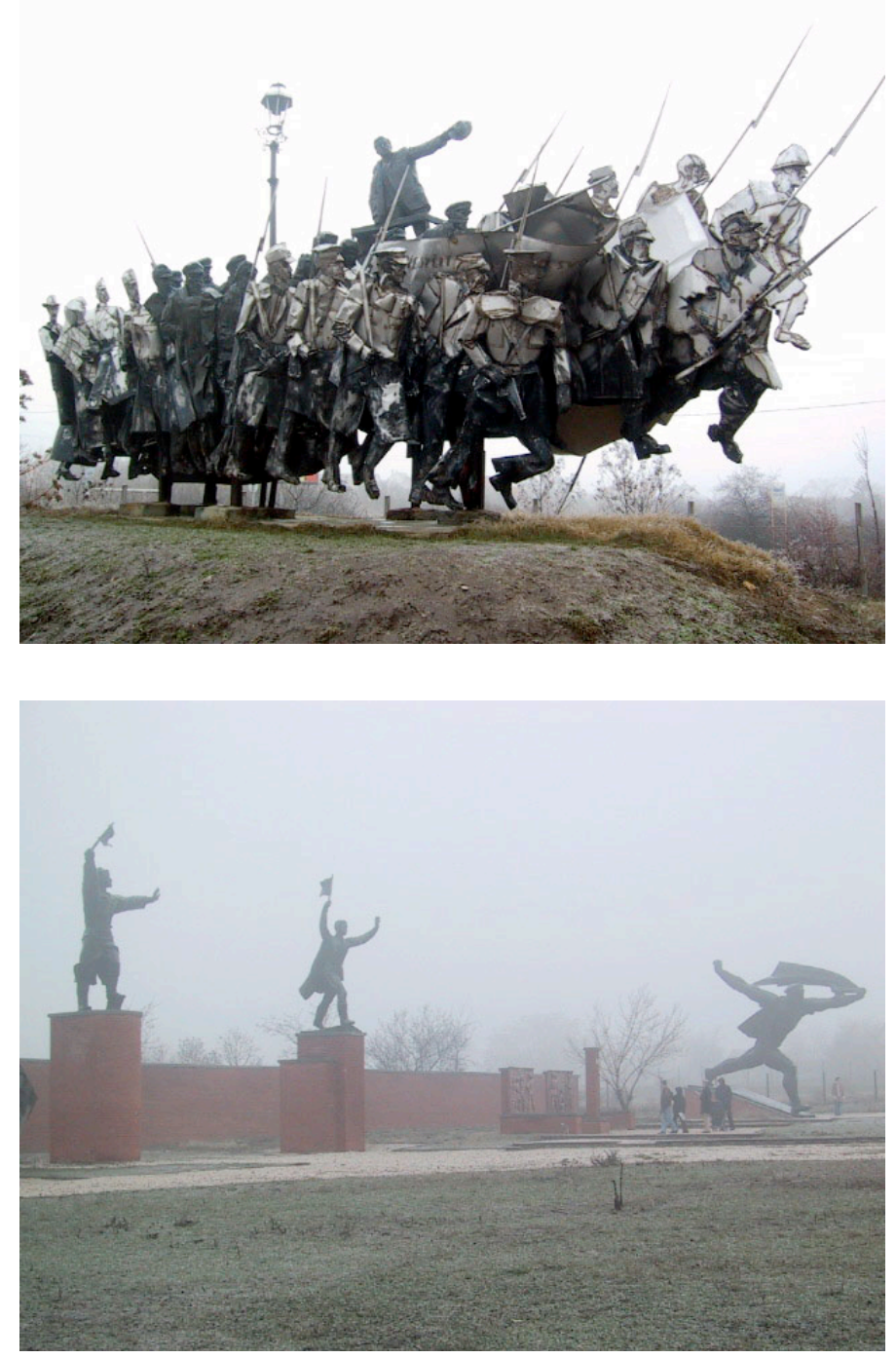

Béla Kun was a Communist leader of the very short-lived Hungarian Soviet Republic, the second Communist government in Europe after Russia, which ruled Hungary for 133 days in 1919. The story goes that, during WWII, Ostapenko and Steinmetz were two Red Army officers and trucebearers, who were brutally killed by the Nazis when they tried to negotiate a truce to save Budapest. After the war, the Communists erected statues to them to remind people of the perfidy of the Nazis and the sacrifice of the Soviets (Rév 2005, 248). As happens so commonly with official stories, irreverence poked its head through, and a popular Hungarian expression of the era became "when Ostapenko changes step" meaning something like "fat chance." Both statues were blown up during the 1956 revolution, but were recast in 1958, and eventually moved to the Statue Park (Margolis 1998). 


\section{ISN'T IT WEIRD THAT THE WORDS CONSUMERISM AND COMMUNISM ARE ALMOST ANAGRAMS OF EACH OTHER?}

The Statue Park is owned by the City of Budapest but operated by a contracted private firm in an economic model well known in the West. The private entrepreneurs have established a small gift shop in the park that sells all manner of items. For example, the music that was playing when we entered the park was from a two-CD set entitled Communism's Greatest Hits, which is available for purchase. Other selections from the CDs include such toe-tappers as "Weave Your Silk, Comrade" and the "Stalin Cantata." (As an aside, I must point out that these communists were not the only ones with a musical bent. Years ago, I bought an album by the Communist Party of Canada-Marxist Leninist, and I still recall some of the tunes. One was a rather witty ditty about a drunk and spectacleless then Quebec premier Rene Levesque who ran over and killed a man on a Montreal street. The opening line was "Rene Levesque doesn't wear his specs. Look out everybody!" Another tuneful number was "The Party Is the Most Precious Thing.")

The concession stand also sells t-shirts with anti-communist slogans, postcards, and memorabilia, such as candles, cigarette lighters emblazoned with Lenin's memorable profile, and models of the Trabant, the infamous East German car. (The Trabant was made of duroplast, a kind of plastic reinforced with wool or cotton. Rumour has it that the plastic material of the Trabant is digestible by pigs, a rumour Kusturica plays with in a scene from Black Cat, White Cat.) The Park sells a poster with a picture of Lenin, Marx and Mao with a caption reading "The Three Terrors," a play on "The Three Tenors," as well as, in a triumph of kitsch, an empty tin can emblazoned with the words "The last gasp of communism."

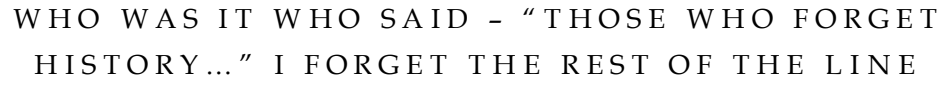

So what is going on with this Statue Park and its kitschy gift shop? Is the park meant to work as a cautionary tale? Pál Haiman, who is about 60, tells us that the park was erected so that Hungarian children could see what the older generation lived through and never repeat those mistakes. My friends with children tell me that it doesn't really work that way. When I ask Evgenia Stoyanova, who grew up Bulgaria, if she thinks the 
park will help people remember history so as not to repeat it, she says, "No. But I'm Eastern European, and I see the glass half empty. Besides, if that was the idea, why aren't the statues displayed downtown, like the statues commemorating WWII? Why are they are moved out of sight to the city outskirts?"

I think it's fair to say that the park arouses many different reactions, depending on the viewer. For me, an interested but distant observer of things Hungarian who grew up in the bubble-world known as Canada, the park was fascinating, strange and bit saddening. Lilla Sipos, a Hungarian scholar currently at the University of Alberta, was about fourteen when the park was erected, and she says of the park: "It was interesting to me because I had always seen those statues standing in the streets and park where I grew up. But my parents seemed to find them... amusing." Pal Heiman sees nothing to laugh about; for him the Park is a reminder of a terrible time in Hungary's history. Yet for others the statues arouse feelings of nostalgia for a time that was perhaps more secure and predictable, in contrast to the state of flux in which the country currently finds itself. The Hungarian economist Magdolna Csath writes: "In Hungary's transformation to capitalism, changes have been imposed on the people, who pay the price in job losses, high unemployment, lack of opportunities to live a decent life, poverty, and a growing gap between the new rich and the many poor. Hungarians are very cynical about the argument that, in spite of all the problems, they at least have democracy and a functioning market economy.... A general sentiment is that the system change only means that those who once had been devoted followers of Karl Marx have transformed themselves into neoliberal capitalists and kept all the capital for themselves" (Csath 2004). Indeed, former Socialist Prime Minster Ferenc Gyurcsány is one the ten richest men in Hungary. Reportedly, when asked about the source of his wealth, he cryptically stated that "he was in the right place at the right time" (cited in Bandy, 2004). This recalls a conversation I had with a Budapest cab driver in 1992. "It used to be," he said, "that we were poor but the government looked after us. Now we are still poor and nobody gives a shit."

This recalls the German term ostalgie (from ost for east and nostalgie for nostalgia), which refers to a longing for life in the former East Germany, particularly for the little things that disappeared after reunification. Indeed, some "businesses in Germany cater to those suffering from Ostalgie. Now available are obsolete brands of East German foodstuffs, old state television programmes on video and DVD, 
and the previously widespread Wartburg and Trabant cars" (http://en.wikipedia.org/wiki/Ostalgie). Ostalgie entered the global imaginary via, not Leander Haußmann's 1999 Sonnenallee, which for many interesting reasons failed to catapult out of the national sphere, but Wolfgang Becker's 2003 Goodbye Lenin, in which an enthusiastically committed socialist and single mother falls into a coma and misses the fall of the Wall. While she is unconscious, Coca-Cola capitalism arrives, her son falls in love her Russian nurse (Lara) and her daughter gets a $m c j o b$ at Burger King. Doctors warn that the shock of the GDR's demise might kill her, so when she wakes up, they keep news of the reunification from her. To convince her that the old world is still in place, they buy unfashionable clothes, obtain increasingly hard-to-get old-regime brands of pickles, and shield her from things like the neighbour's satellite TV, and in doing so, they create a facsimile of the old perfect order.

\section{E - I D E - W H A T?}

The Statue Park website says that the Park is unique in Central Europe, though there is such a park in Lithuania, and Moscow has its Park of the Arts, which Svetlana Boym discusses in The Future of Nostalgia. Unlike in Hungary, at the collapse of the Soviet Union people toppled statues as though they were chess pieces (as also occurred in Bulgaria, where, Evgenia and Ivanka Stoyanova tell me, "In the euphoria immediately after the resignation of our long-presiding dictator in 1989, most of the statues were pillaged. Some were melted to be used in new pieces, though this was actually quite rare because the municipalities didn't have money for art; most of the statues were stolen by poor people who sold them for recycling. The situation in smaller towns - the stronghold of communist nomenklatura for years - was much different. The communist statues there lasted much longer. But now it's a rarity to see one standing.") Meanwhile back in Russia, Boym tells us that many of the downed Russian monuments, defaced and covered with graffiti, ended up in a park in Moscow where they were left to decay. Imagine her amazement, when, in 1997, she returned to Moscow to find the statues, including Dzerzhinsky, the head of the secret police, and Stalin, not only re-erected but standing in a park among on oddly disparate group of figures including Adam and Eve, Gandhi and Don Quixote. All the graffiti had been removed and the statues bore explanatory plaques with banal details as well as this piece of bureaucratese: "This monument has 
historical and artistic significance. The monument belongs to the memorial constructions of the politico-ideological thematics of the Soviet Union. Protected by the state." This was not a totalitarian sculpture garden, writes Boym $(2001,84)$ "but something much more ordinary and pleasant. Such words as totalitarian were simply out of place here. The Park of Arts [featured] a path of roses and a cafeteria that sold Russian perogi under cheerful Coca Cola umbrellas.... The Park of Arts is about de-ideologization." Boym suggests that perhaps Russian people are tired of symbolic battles and of new revelations of past Soviet atrocities. "If there is a nostalgia at the end of the millennium, it seems to be post-historical; it is a longing for a life of peace and plenty... the park succeeds in removing any trace of estrangement or ambiguous attitude toward the past. The place isn't even particularly nostalgic, being beyond the dialectics of remembering and forgetting, history has become spatialized, the art of memory has turned into the art of leisure." (91)

I think it's safe to say that Budapest's Statue Park, which Istvan Rév refers to as the "ghetto of socialist memorials, where the dead sculptures await the last judgment" (2005, 273), is not an expression of deideologization. Though architect Eleöd says that the Park is "about dictatorship, and democracy," it is also about the ideological system that produced the park. That is, the grouping of the statues into a kind of petrified zoo, the music, and the kitschy souvenirs combine to serve the agenda of the anti-communist conservative governments that followed the 1990 defeat of the communist/socialists. Communism is made to seem preposterous, a "what was I thinking" minute that lasted for decades, and as we shall see, this conservative ideological thread winds its way all the way to the House of Terror. Walter Benjamin notably observed that the aura that surrounds a work of original is lost when the object is reproduced; though the statutes in the Statue Park are one-offs and not mass produced (although there is a decided sameness to the many busts of communist functionaries), nevertheless, the grouping of the statues in this "kind of statue concentration camp serves to remove their aura" (Anselmi 2005). And the tacky but prosperous little store selling trinkets (a bottle of air for 10 dollars US!? - at least the Italian artist Manzoni put excrement in his cans!) suggests that, in the case of the Hungarian consciousness, capitalism won a decided victory. In Retroactive Justice: Prehistory of Post Communism, Rév discusses how prevailing ideologies compete over myths and the power to interpret them, and he relates another version of the Ostapenko and Steinmetz story that surfaced after the system change. Before 1989, Ostapenko and 
Stienmetz were heroes and symbols of the friendship between Hungary and the then USSR. Since 1989, though, "a new anti-communist historiography" has suggested that the Soviets shot Ostapenko in the back by mistake while Steinmetz drove his car off the road while drunk and killed himself (Rév 2005, 129).

So what has replaced the statues? A cynic would mention McDonald's Golden Arches or KFC. Despite the obvious presence of such wonderful American cultural symbols, Budapest still has lots of political statues (of Kossuth, Petőfi and Széchenyi, for example) that stand the test of time because their subjects belong to a more distant, more heroic and unproblematic past. As well, other kinds of memorials have sprung up, notably to such figures as Raoul Wallenberg, the Swedish ambassador credited with saving anywhere between 20,000 and 100,000 Hungarian Jews, and to victims of the Holocaust. Indeed Budapest's synagogue, the largest in Europe, has a stupendous Holocaust memorial.

\section{BUDAPEST'S HOUSE OF TERROR: THE SZOBOR PARK'S TWISTED SISTER}

Opened in 2002, the House of Terror is a museum dedicated to the past atrocities of both the fascists and the communists. It is located at 60 Andrássy Boulevard, one of Budapest's grandest streets and a UNESCO World Heritage site. The actual building at 60 Andrássy served as the headquarters for two brutal regimes: first for the Arrow Cross party, the extreme right-wing party that came to power in 1945 under the leadership of Szalási. Then, after the end of the war, for the communists, who deliberately chose the same building for the headquarters of the secret police (the AVO, renamed AVH).

The House of Terror is completely grey. A black frame around the roof is decorated with the perforated words terror as well as an arrow cross, symbol of the fascists, and a star, a symbol of the communists. When the sun shines through the perforations, the word terror and the two symbols appear on the building's walls. And, as though one were attending a theatrical performance, a limited number of visitors are allowed entry at one time; the influx is closely monitored by unfriendly guards. And the dual entry fee system is reminiscent of communist days - foreigners pay about $\$ 13$ US to get in, twice as much as Hungarians.

In the museum's atrium stands a Soviet tank alongside a wall of portraits of some of the people killed in the building. Displays include 
scenes of gulag life, socialist realist art and a labyrinth of bricks made from pork fat, meant to remind people of the hard times of the 1950s (Steves 2005). As one descends in an elevator to the basement torture chambers, a lugubrious video explains how people were executed. In the final room, a TV shows recorded live coverage of the 1989 reburial of Imre Nagy, the leader after the ' 56 revolution, who was executed by the communists, and a 1989 speech by the right-wing politician (and, to some, dangerous irredentist and anti-Semite) Viktor Orbán, ordering the Russians to leave Hungarian soil. Orbán was a founding member of Fidész (Fiatal Demokraták Szövetsége, the Alliance of Young Democrats), which he helped transform from an anti-communist student movement into a conservative party. Fidész gained power in 1998 under Orbán, who governed Hungary in coalition with the smaller Hungarian Democratic Forum until 2002, when the Socialist party won the election. Orbán was Prime Minister when the House was opened.

At the Statue Park, monuments to a political era and ideology are displayed out of context: the viewer is therefore forced to reassess and reformulate their meaning but is also allowed some emotional distance. The kitschy humour serves to undercut much of the emotional impact. At the House of Terror, on the other hand, the house itself is the actual scene of terrible events, which included torture and show trials of Hungarian citizens. The names of actual people, some of them still living, are listed on the wall of perpetrators. There is no distance here between the viewer and the thing viewed, for the viewer is inside the belly of the beast itself, as it were. Further, the mediated images - that is, the videos and photographs, as well as the melodramatic soundtrack and the way visitors' movements are almost choreographed - stimulate the senses not the mind, and in the words of Istvan Rev, arouse a "weird fascination" (293).

This House has caused much controversy in Hungary. László Karsai, one of Hungary's top Holocaust scholars, suggests that the creators of the House, working under the right-wing government of Viktor Orban, tried to draw a line between the communist torturers and left-of-centre politicians of the present. "The message is simple," he notes, "Almost every Hungarian is innocent. The main guilty are foreign forces; first the Germans, then the Russians, then the very few collaborators. Therefore, today only a collaborator could vote for a socialist or a liberal" (as cited in Kim 2003). 
Rév $(2005,293)$ draws an eerie parallel between the House of Terror and the "Mostra della rivoluzione fascista," the exhibit of the fascist revolution, opened in October 1932 by Mussolini, about which he writes:

The distance between fact and fiction, construction and reconstruction, genuine historical documents and artistic re-creation disappeared. The ephemeral space swallowed up the viewers, who were denied the detachment needed for contemplation or just for understanding the sight. The ambition... was to build a total, self-contained environment, the apotheosis of the movement and of the Duce, that aimed at not the rational but the emotional reactions of the visitors, immersed in the flow of the unexpected visual and rhetorical impulses. (294)

Two of the House's rooms are dedicated to the fascist atrocities that killed over 600,000 Jewish, Roma and left-wing citizens of Hungary, while twenty-five rooms focus on the communist era, which is reported to have claimed 3000 victims. Notice that I did not write only $3000-$ making such a distinction would be morally repugnant, but someone decided what to display in this House and how, so one is entitled to ask "who" and "why."

\section{UNEASY B EDFELLOWS}

If, as the Hungarian novelist György Konrad wrote, "Faiths, myths and memory live side by side," they do not do so easily. Instead they crash into each constantly, like bumper cars on a midway, especially in societies undergoing major transformations. As Hungary tries to get its footing in that great sorting mechanism known as the market economy, one hopes that its people can overcome divisive political polarization, which, since the system change, has seen it seesaw politically from right to left like a yoyo. The Hungarian winner of the 2002 Nobel Prize for literature, Imre Kertész, also sees the problematic effect of this simplistic approach to history: "After 1989, no one accepted that they made the choice to collaborate. Overnight everyone became a dissident. One lie replaced the other, and that's a problem all of Eastern Europe still has to deal with." He goes on to say that, "The conflict not between nations but between rationalism and fanaticism, between cultures that cannot understand each other, is very, very dangerous." 


\section{WORKS CITED}

Anselmi, William. Personal communication. October 1, 2005.

Austrian Cultural Institute. Occasions: Central Europe. Vienna, Austria: Austrian Cultural Institute, 1998.

Bandy, Alex. "Hungarian Soufflé: the Communist System in Hungary Was Not Overthrown. It Simply Imploded." The New Internationalist. April, 2004.

Benjamin, Walter. "The Work of Art in the Age of Mechanical Reproduction." Available on line at www.marxists.org/reference.subject/philosophy/works/ge/benjamin.htm. 1936. Accessed October 27, 2005.

Boym, Svetlana. The Future of Nostalgia. New York: Basic Books, 2001.

Clark, Toby. Art and Propaganda in the Twentieth Century. New York: Harry N. Abrams, 1997.

Csath, Magdolna. "Hungary's Turbulent Transformation to Capitalism: Corruption, Mismanagement Exemplify 'new' Europe's Challenges." The Futurist. Sept-Oct 2004, v38 i5 p 17(3).

Kim, Lucian. "Budapest Revisits Its Recent Horrors: Museum Stirs Debate on the Past." Boston Globe, April 6, 2003.

Konrád György. "The Best of Both Worlds: Still Straddling East and West, Berlin Would Become Central Europe's World-Class City." Time, Nov 20, 1989.

Margolis, Sam. "Postcard from Budapest: When Comrade Ostpaneko Changes Step, Dictatorship and Democracy Will Agree." National Post, December 26, 1998, p A11.

Rader, Malcolm and Jessup, Bertram. Art and Human Values. Prentice Hall, Englewood, NJ: 1976.

Rév, István. Retroactive Justice. Stanford: Stanford University Press, 2005.

Steves, Rick. "Budapest's House of Terror." Available on line at ricksteves.com/plan/destinations/eastterror.htm. Last accessed October 16, 2005.

Stoyanova, Evgenia and Stoyanova, Ivanka. Personal communication. October 21, 2005.

Thomas, Evan. "The Tricks of Memory (Political Nostalgia). Newsweek. December 26, 1994 124(6) p 40.

Vitali, Alessandra. "Budapest, un museo del regime i marmi di Lenin e Marx ai giardinetti." La Republicca, Oct 18, 2005. 